\title{
Consensus statement on the initiation and continuation of tumour necrosis factor blocking therapies in rheumatoid arthritis ${ }^{\star}$
}

Josef S Smolen, Ferdinand C Breedveld, Gerd R Burmester, Bernard Combe, Paul Emery, Joachim R Kalden, Lars Klareskog, Ravinder N Maini, Raffele Numo, Leo B A van de Putte, Piet L C M van Riel, Vicente Rodriguez-Valverde

This group of rheumatologists gathered in Vienna out of concern about the absence of a uniform view and guidance on the introduction of tumour necrosis factor (TNF)-blocking therapies in our clinics. With our growing experience, evaluation of drug treatment of rheumatoid arthritis (RA), and previous participation in consensus statements, ${ }^{1}$ we have had the opportunity of discussing the accrued knowledge as well as personal experiences in the use of TNF-blocking agents and of formulating our jointly shared views on:

- Indications for starting TNF-blockade therapy

- Deciding what levels of disease activity would be most appropriate to continue (or discontinue) TNF-blocking therapy.

For the present, TNF blockade should be reserved for patients with RA whose symptoms and signs are resistant to disease modifying antirheumatic drug (DMARD) treatment. It is generally agreed that all patients with active disease should be treated with DMARDs, as such treatment ameliorates symptoms and slows progression of structural damage. ${ }^{2}$ However, long term efficacy of DMARDs is limited and toxicity accumulates. ${ }^{3}$ Currently, two TNF-blocking agents, etanercept and infliximab, have received regulatory authority approval for the treatment of RA. Both compounds, alone or in combination with methotrexate, have proved to be successful in significantly reducing inflammatory activity and increasing the quality of life. ${ }^{4-8}$ In addition, infliximab in combination with methotrexate has been shown to arrest radiographic progression over one year in up to $50 \%$ of patients, while etanercept has been shown to retard radiographic progression significantly in DMARD-naive patients. ${ }^{10}$ Nevertheless, in early RA, the superiority of TNF-blocking agents over DMARD treatment has not yet been clearly demonstrated.

At present, patients eligible for TNFblocking agents are those with an inadequate response to one or more DMARDs, including methotrexate. Before treatment, an individual goal should be established for each patient by the treating physician (who should be experienced in the diagnosis and treatment of RA, including the use of immunoregulatory agents), and this goal should aim at achieving low disease activity or even remission. Patients generally should have active disease defined, for example, by the Disease Activity Score, DAS28 $>3.2^{11}$ or a combination of five or more swollen and painful joints as well as an abnormal acute phase response. It should be noted that individual patients experience varying degrees of aggressive disease as well as symptoms and signs and impact of the disease on their quality of life. All these factors must be taken into account when considering TNF blockade, as must the limitations of previous DMARD treatment due to toxicity. TNFblocking agents can be added to pre-existing methotrexate treatment. Patients with insufficient response to a single DMARD other than methotrexate should not be treated with TNFblocking agents before methotrexate has been tried, unless contraindicated. Methotrexate should be used in adequate doses before its inefficacy is declared-that is, in current practice up to $25 \mathrm{mg}$ a week, ${ }^{12}$ if tolerated. Also, patients whose earlier DMARD treatment had been discontinued because remission had been achieved should be retreated with this previously effective DMARD.

Initiation of TNF-blocking therapy should be accompanied by a complete physical examination and a chest $x$ ray examination to exclude contraindications. $x$ Rays of hands and feet performed at baseline and at yearly intervals are useful to monitor structural damage to joints. Contraindications to TNF-blocking therapy, listed in the package inserts or summaries of product characteristics, provide the necessary guidance on which patients should not be treated. In particular, patients with acute or chronic infections, such as tuberculosis, or with recent malignancies, should be excluded.

Response to TNF-blocking therapy should be assessed by validated response criteria-for example, the EULAR or ACR response criteria. ${ }^{13}{ }^{14}$ These require numerical evaluation of the number of tender and swollen joints (for example, using the 28 joint count) and an acute phase response (for example, erythrocyte sedimentation rate or $\mathrm{C}$ reactive protein, or both),
*Professor Barry Bresnihan was the acting editor for this paper. 
and other appropriate measurements - for example, patient and/or physician global assessments (visual analogue scale (VAS) or five point scale), pain assessment (100 mm VAS), and functional assessment (such as the Health Assessment Questionnaire). As a guideline we suggest that the decision to continue TNFblocking therapy requires minimum improvement in the DAS2 8 score of $\geqslant 1.2$ or a DAS28 $\leqslant 3.2$ or at least a $20 \%$ improvement by ACR improvement criteria.

Non-responders should discontinue TNFblocking therapy. A patient should be regarded as a non-responder, if the response criteria are not met within an observation period of eight to 16 weeks from the start of treatment according to recommended dosing schedules of drugs, and every 16 weeks thereafter. Major adverse events attributable to TNF-blocking therapy obviously require prior termination. At the present time, it is not known if lack of response to one anti-TNF treatment principle will equate with a lack of response to another.

Clearly, at present, TNF-blocking agents do not cure RA and their discontinuation is usually associated with a relapse of RA after varying periods of time. ${ }^{15}$ It has not been investigated yet, whether TNF blockade can be used to induce significant improvement or remission and then be replaced by conventional DMARD treatment. Also, it has not yet been established, if and how, dose and interval may be adapted during long term treatment with TNF-blocking agents. Such questions clearly have to be included in a future research agenda.

The group was aware that healthcare systems differ widely between countries. Therefore this consensus and opinion of experts, most of whom have long term experience with one or more TNF-blocking compound, should only be regarded as a general framework for the initiation and continuation of TNF-blocking agents in RA, from which specific conclusions that better fit the situations in individual countries can be derived. A standardised approach for the indication of, and evaluation of the clinical response to, TNF-blocking therapy in RA could constitute an important advancement towards improved overall quality of management of this crippling disease.
The meeting was supported by an unrestricted educational grant from Schering-Plough Corporation.

1 Furst DE, Breedveld FC, Burmester GR, Crooford L, Emery P, Feldmann $M$, et al. Consensus statement: Access to disease modifying treatments for rheumatoid arthritis patients. Ann Rheum Dis 1999;58 (suppl I):129-30.

2 van der Heijde DMFM, van Riel PLCM, Nuver-Zwart ICH, Gribnau FW, van de Putte LB. Effects of hydroxychloroquine and sulphasalazine on progression of joint damage in rheumatoid arthritis. Lancet 1989;i:1036-8.

3 Felson DT, Anderson JJ, Meenan RF. Use of short-term efficacy/toxicity tradeoffs to select second-line drugs in rheumatoid arthritis. A metaanalysis of published clinical trials. Arthritis Rheum 1992;35:1117-25.

4 Elliott MJ, Maini RN, Feldmann M, Kalden JR, Antoni C, Smolen JS, et al. Randomised double-blind comparison of chimeric monoclonal antibody to tumour necrosis factor $\alpha$ (cA2) versus placebo in rheumatoid arthritis. Lancet 1994; 344:1105-10.

5 Moreland LW, Baumgartner SW, Schiff MH, Tindall EA, Fleischmann RM, Weaver AL, et al. Treatment of rheumatoid arthritis with a recombinant human tumor necrosis factor receptor (p75)-Fc fusion protein. N Engl J Med 1997;337:141-7.

6 Maini RN, Breedveld FC, Kalden JR, Smolen JS, Davis D, Macfarlane JD, et al. Therapeutic efficacy of multiple intravenous infusions of anti-tumor necrosis factor $\alpha$ monoclonal antibody combined with low-dose weekly methotrexate in rheumatoid arthritis. Arthritis Rheum 1998;41: 1552-63.

7 Maini RN, St Clair EW, Breedveld F, Furst D, Kalden J, Weisman $M$, et al. Infliximab (chimeric anti-tumour necrosis factor $\alpha$ monoclonal antibody) versus placebo in rheumatoid arthritis patients receiving concomitant rheumatoid arthritis patients receiving concomitant
methotrexate: a randomised phase III trial. Lancet methotrexate: a

8 Weinblatt ME, Kremer JM, Bankhurst AD, Bulpitt KJ, Fleischmann RM, Fox RI, et al. A trial of etanercept, a recombinant tumor necrosis factor receptor: Fc fusion protein, in patients with rheumatoid arthritis receiving methotrexate. N Engl J Med 1999;340:253-9.

9 Lipsky P, St Clair W, Furst D, Breedveld F, Smolen J, Kalden JR, et al. 54-week clinical and radiographic results from the ATTRACT trial: a phase III study of infliximab in patients with active RA despite methotrexate. Arthritis Rheum 1999;42 (suppl):401.

10 Finck B, Martin R, Fleischmann R, Moreland L, Schiff M, Bathon J. A phase III trial of etanercept vs methotrexate (MTX) in early rheumatoid arthritis (ENBREL ERA trial). Arthritis Rheum 1999;42 (suppl):117.

11 Prevoo MLL, van't Hof MA, Kuper HH, van Leeuwen MA, van de Putte LB, van Riel PL, et al. Modified disease activity scores that include twenty-eight-joint counts. Arthritis Rheum 1995;38:44-8.

12 Weinblatt ME. The role of current strategies in the future treatment of rheumatoid arthritis. Rheumatology 1999; 38(suppl 2):19-23.

13 Van Gestel AM, Anderson JJ, van Riel PLCM, Boers M, Haagsma CJ, Rich B, et al. ACR and EULAR improvement criteria have comparable validity in rheumatoid arthritis trials. J Rheumatol 1999;26:705-11.

14 Felson DT, Anderson JJ, Boers M, Bombardier-C, Furst-D, Goldsmith-C, et al. The American College of RheumatolGoldsmith-C, et al. The American College of Rheumatology preliminary definition of improvement

15 Elliott MJ, Maini RN, Feldmann M, Long-Fox A, Charles $\mathrm{P}$, Bijl H, et al. Repeated therapy with monoclonal antibody to tumour necrosis factor alpha (cA2) in patients with rheumatoid arthritis. Lancet 1994;344:1125-7. 